the Empire requires. It may be, and we are inclined to think that it is, necesary that the external degree should be continued and maintained. It ought to be easy to devise a machinery for doing this that is not inconsistent and incompatible with the ideals laid down by the Commissioners.

All those concerned in the work of higher education in London-and, indeed, in the country generally-should combine to help in this scheme. There must be give and take. The incorporation principle already adopted by University and King's Colleges was in itself a surrender of autonomy, and other institutons must be prepared to make similar sacrifices if the University is to be a reality. The Minister puts this point well when he says, "Some acquiescence or even sacrifice on individual points will be necessary for all concerned if a scheme worth having is to be carried out."

\section{THE PLUMAGE BILL.}

$\mathrm{N}$ the great question of fauna preservation the 1 newspaper-reading public is at present occupied with the section concerning birds. It is announced by the Royal Society for the Protection of Birds that Mr. Hobhouse will, when Parliament reassembles, bring forward a Bill for restricting the import of plumage into the United Kingdom, and that this Bill will be backed by the President of the Board of Trade and the Under Secretary for India. In its monthly journal, the aforesaid society publishes what purports to be the text of this Bill. It is a very mildly worded measure which will not satisfy root-and-branch reformers, for it exempts from supervision personal clothing worn or imported by individuals entering this country from abroad. Consequently-unless I totally misunderstand the drift of the Billworded, like all Bills, with as much legal obscurity as possible-a woman resolved to have headdresses and robes of forbidden plumage has only to purchase such abroad and stick it into her apparel or her hat, and she passes our Customs houses unchallenged. If my reading is correct, then the results of this Bill will be very slight in stopping the destruction of rare and beautiful wild birds in the British dominions and the colonial empires of France and Holland. But I agree with the R.S.P.B. in welcoming any legislation rather than none, as the thin end of the wedge. We must remember that the first antislave trade measure (fought and delayed for many years by spiritual ancestors of the type of plumagetrading firms) was a poor and ineffective thing. But as soon as its justification was grasped by the public it was reinforced by much more drastic legislation.

Mr. James Buckland is quite right to direct attention in vigorous language to the disgraceful amount of beautiful-bird destruction which is going on in Nipal. This quasi-independent Himalayan State has-unhappily - been placed by fate in charge of the most interesting faunistic region of Asia, a country not many years ago famous for the variety and superb beauty of its harmless bird life, notably its pheasants. Originally the Nipalese respected almost religiously the fauna of their native land, like most Indian peoples. But of late they have become infected with a truly British love of life-destruction. They are incited to this by the agents of the plumage trade at Calcutta and other places, and, of course, find it a lucrative business. As in all things but foreign relations we acknowledge the state of Nipal to be an absolutely independent kingdom, it is permitted to import and export goods through British India under its own Customs' seals, intact and unquestioned.

Consequently, though the laws of British India forbid on paper the export of wild birds' plumes or skins, the State of Nipal monthly exports from Calcutta to the feather markets of the worldprincipally London - thousands of bird skins. The Nipalese have nearly exterminated the Monal pheasant, the Tragopan, and several other gallinaceous marvels. The few people who know and protest on this side are told that Nipal is an independent state and cannot be coerced. But there is no need for coercion. We regulate with Nipal the arms traffic and the opium traffic, and we can easily add to the list of prohibited traffics that in the plumage of rare birds or the skins and trophies of rare mammals. The Nipalese Government, after all, is civilised and can easily be brought to understand that we make our request in the interests of Nipal itself. We have many ways of obliging and disobliging Nipal without resorting to "coercion" in what is really-rightly viewed-a matter of religion.

But of course the weakness of our case and cause is that the present Cabinet-and past Cabinets-and all our Government departments care little or nothing about fauna preservation. They, owing to the faulty education of their component personalities in the preceding century, are unable to view the question from its æsthetic as well as its economic point of view. Consequently few of our London-governed colonies have adequate bird-preservation regulations; while the whole attitude of British India and Burma towards its wonderful and fast-disappearing fauna is one of the scandals of the age. If it were not that the Native States of the Indian Empire have and enforce, so far as they dare, game preservation and bird preservation laws, the Indian peninsula would be now almost lacking in all the more noteworthy types of wild bird and beast. The game regulations drafted by the Viceroy-in-Council for British India were published last year by our own Zoological Society, and forthwith so laughed at for their inadequacy and old-fashioned "gamepreserving " character, that they seemingly found their way into the waste-paper basket. At any rate, no far-reaching regulations for fauna preservation have since been published and put in force.

Let scientific men take a broad and lofty view of this question of fauna preservation. Why should any beasts or birds not actively harmful to man or man's interests be killed, except where

$$
\text { NO. } 2302 \text {, VOL. } 92]
$$


they are required to provide palatable food for hungry humanity? Why should any more ibexes, markhur, deer, wild sheep, antelope, bear, and such like wonders of creation be destroyed in India, at any rate till by increase in numbers they are prejudicial to the agriculturist? Why should they be killed merely to provide trophies for British officers or tourists, when their life-history is of profound interest and can be studied through the camera, and their presence in the landscape is a source of delight to the eye? Why, similarly, should any beautiful birds that are not harmful to crops be killed anywhere for the ridiculous purpose of adorning already-sufficiently-adorned woman? We would-be bird preservers do not object to the unlimited use of ostrich plumes, because such use is supported by the domestication of the ostrich; we do not include the eider duck on our prohibition lists because its down feathers can be obtained without killing the producer; we do not refuse to the trade or the lover of beautiful objects the plumage of several kinds of duck and pheasant, because such can be obtained without bringing these particular types of bird near to extinction. In short, there is enough plumage in quantity and variety to supply all the needs of milliners, dress-makers-and-wearers, upholsterers, and even the purveyors of artificial flies for fly-fishing, without trenching on the rare and specially marvellous birds of the world, or the birds that are of incalculable use as insect destroyers and guano producers.

The apologists of the trade in forbidden birds' skins, or the defenders of the unchecked slaughter of interesting mammals by the rifle, are of a sadly limited type of mentality, so limited that an educated naturalist is not on the same mental plane. Though he can easily parry their arguments, he cannot get them to understand his. But perhaps the foes of Mr. James Buckland who attend to harass him at his lectures are, together with their salesmen-colleagues at London auctions, remarkable beyond others of their class for their want of knowledge of the article they trade in and the local methods of their trade. They do not know for the most part the right name in English or Latin or the approximate habitat of the birds they deal in. As to how the skins are procured, they probably only know that they bought them in Antwerp, Paris, Havre, Amsterdam, Bordeaux, Marseilles, Trieste, Port Said, Calcutta, or Port-of-Spain. They have no knowledge of and no responsibility for the actual half-caste or native agents who do most of the killing or snaring. Occasionally, sorne specially important firm undertakes a commission for a rich curio-collecting client, and sends out an agent to some distant region to get into touch with the native hunters, but such a firm would scarcely take as much trouble over the bulk of its business--the supply of the millinery houses.

As an illustration of the foregoing remarks, I should like to insert a passage from the writings of Mr. W. Emery Stark, which appeared a few months ago in The Times of Ceylon:-
The Trade in Birds of Paradise.

The Papuans (of Dutch New Guinea) are engaged by the traders to act as "hunters." The season, which begins in April, lasts for six months, and for the remaining six months of every year the Papuan spends his time in paddling about, and his money in buying ornaments and luxuries. There is a regular and well-organised trade in birds of paradise. The centre of the trade is at Ternate, where the traders live, and from where they start every year in March for New Guinea. The traders are chiefly Chinese, but there are two or three Dutch trading companies. The Government issue licences for hunting at 25 guilders, or about $2 l$. a gun, and, in addition, the Government charge a heavy export duty on the birds. This year there were 4000 applications for licences, of which 1870 were granted, and one trading company alone secured 240 licences. The traders engage the natives as "hunters," paying the licence and finding guns and ammunition. Each "hunter" is expected to bring in for the season 20 skins of the "great bird of paradise" and 50 to 60 of the ordinary and less valuable sort. The former command at their first price from rooo to r200 guilders, or roughly rool. per "corge," i.e. 20 birds. In the home market a "corge" realises from $150 l$. to r $70 l$., and a single bird of extra fine plumage has been known to fetch as much as $40 l$. or more. A rough calculation of the I870 licences issued this year, show that they are likely to result in the production of about 200,000 skins.

I wish the Government had received a steadier backing in the matter of fauna-preservation from the Zoological Society and the British Ornithologists' Union. The attitude of the latter seems to be that so long as museum shelves are stuffed with specimens, birds may be in the landscape or not. The last thing I desire to do is to fetter the researches of professional science. But I would remind fellow ornithologists that it is not only the skin of the bird for classification that is needed, but still more the bones, the muscles, and the viscera, and the living creature itself. This is not the material supplied by the trade collector. Yet, as a concrete example, look at the remarkable deductions in biology which have followed the illustration of the cæca and intestinal tracts in birds and mammals by Dr. Chalmers Mitchell; or the work of A. H. Garrod and F. E. Beddard in myology and windpipes. It is this material which is wanted by the biologist more than an endless multiplication of empty skinsthis and the life-study through the camera and the note-book; and all such food for systematists and expounders of the New Bible could be supplied by game-wardens and those who should be placed in control of the wild fauna of our dominions.

H. H. Johnston.

Since the foregoing article was written, there has been placed in my hands a copy of a Government notice recently issued in Egypt-we may be sure not without Lord Kitchener's knowledge and approval-referring to the shooting of animals. Lord Kitchener is no sentimentalist; but alike in his reports and his acts he has continuously used his influence for the preservation of bird-life in Egypt. 